\title{
ANALISIS KETERAMPILAN PROSES SAINS DASAR PADA BUKU TEMATIK KELAS V TEMA PANAS DAN PERPINDAHANNYA
}

\section{AN ANALYSIS OF BASIC SCIENCE PROCESS SKILL ON THE THEMATIC BOOK FOR CLASS V ESPECIALLY THE HEAT AND ITS MOVEMENT THEME}

\author{
Yuliananingsih ${ }^{1}$, Mohamad Agung Rok himawan ${ }^{2}$ \\ ${ }^{1,2}$ Fakultas Ilmu Tarbiyah dan Keguruan UIN Sunan Kalijaga Yogyakarta \\ ${ }^{1,2}$ Jalan Marsda Adicipto Yogyakarta \\ Email: 19204080004@ @tudent.uin-suka.ac.id ${ }^{1}$, rokhimaw an78@ gmail.com $^{2}$
}

Submitted: 21-12-2019, Revised: 16-06-2020, Accepted: 20-06-2020

\begin{abstract}
Abstrak
Penelitian inibertujuan untuk menganalis is keterampilan proses sains das ar pada buku tematik kelas $\mathrm{V}$ tema panas dan perpindahannya. Metode y ang digunakan adalah metode penelitian kepustakaan dengan buku yang dianalis is yaitu buku tematik siswa kelas $\mathrm{V}$ tema panas dan perpindahannya karya Diana Karitas dan Fransiska terbitan Kementrian Pendidikan dan Kebudayaan. Pengumpulan dan peninjauan indikator referensi untuk keterampilan proses sains yang kemudian dihubungkan dengan materi sains di buku siswa tema panas dan perpindahannya. Peneliti menganalis is data yang terkait dengan penggunaan induktif dan deduktif. Adapun hasil penelitian menunjukkan bahwa: (1) setiap subtema telah merujuk pada pendekatan pembelajaran keterampilan proses sains, dan (2) setiap sub-tema adalah keterampilan proses sains dasar, yaitu observasi, komunikasi, inferensi, pengelompokkan, dan penalaran.
\end{abstract}

Kata Kunci: Keterampilan Proses Sains Dasar, Tematik, Sekolah dasar

\begin{abstract}
This research aimed to analyze the basic science process skill on a thematic book especially the theme ofheat andits movement. The method used was the library research to analyze a thematic book especially the heat and its movement theme for the fifth grade students which was written by Diana Karitas and Fransiska and published by the Ministry of Education and Culture. The collection and review of reference indicators for science process skill were then linked to science material of the students' thematic book especially the heat and its movement. The researchers analyzed the related data to the inductive and deductive use. The findings indicated that: (1) each sub-theme had referred to the approach oflearning science process skill, and (2) each sub-theme was the basic science process skill namely observation, communication, reference, grouping, and reasoning.
\end{abstract}

Keywords: Basic Science Process Skill, Thematic, Primary School

How to Cite: Yuliananingsih, \& Rokhimawan, M. A. (2020). Analis is Keterampilan Proses Sains Dasar pada Buku Tematik Kelas V Tema Panas dan Perpindahannya. AULADUNA: Jurnal Pendidikan Dasar Islam, 7(1), 81-89.

\section{Pendahuluan}

Pendidikan merupakan proses dalam rangka mengembangkan kemampuan, keterampilan dan kepribadian dari siswa. Sesuai dengan interpretasi pendidikan yang tertuang pada Undang-Undang Republik Indonesia nomor 20 tahun 2003 tentang sistem 
pendidikan nasional yang menyatakan bahwa "Pendidikan merupakan usaha sadar dan terencana dalam rangka mewujudkan suasana belajar dan proses pembelajaran agar siswa secara aktif mengembangkan potensi yang dimiliki dirinya untuk memiliki kekuatan spiritual keagamaan, pengendalian diri, kepribadian, kecerdasan, akhlak mulia, serta keterampilan yang diperlukan dirinya, masyarakat, bangsa, dan negara" (Pemerintah Indonesia, 2003). Pendidikan nasional berfungsi untuk mengembangkan kemampuan dan membentuk watak serta peradaban bangsa yang bermartabat dalam rangka mencerdaskan kehidupan, mengembangkan potensi siswa agar menjadi manusia yang beriman dan bertakwa kepada Tuhan Yang Maha Esa, berakhlak mulia, sehat berilmu, cakap, kreatif, mandiri, dan menjadi warga negara yang demokratis, serta bertanggung jawab.

Selaras dengan evolusi paradikma dunia mengenai makna dari pendidikan, pendidikan pada era sekarang dihadapkan dengan berbagai tantangan. Salah satu tantangannya yaitu pendidikan seyogianya menghasilkan sumber daya manusia yang mempunyai kompetensi yang komplit. Berbeda dengan sepuluh tahun yang lalu, kompetensi yang perlu dimiliki oleh sumber daya manusia khususnya siswa yaitu kompetensi yang menitikberatkan pada berpikir dan komunikasi. Mewujudkan khitah dari sistem pendidikan nasional tersebut adalah dengan selalu meningkatkan kualitas pendidikan dan pengajaran yang dimiliki di negara ini. Salah satu usaha yang dilakukan oleh pemerintah dalam muwujudkan dan memperbaiki pendidikan sekarang yaitu dengan pengadaan buku ajar di sekolah, khususnya pada MI/SD. Ketersediaan buku ajar yang berkualitas akan membantu dan mendukung proses pembelajaran. Buku ajar dapat berdampak positif dalam memberikan kepandaian dan pengalaman kepada proses belajar siswa. Buku dapat menjadi bagian sumber belajar yang turut dapat menentukan tercapai tidaknya tujuan dari pembelajaran (Martatik, 2018: 105).

Buku teks adalah salah satu perangkat pendidikan yang perannya strategis dan ikut mempengaruhi mutu dan kualitas pendidikan, karena bisa berfungsi sebagai sumber belajar dan media yang sangat urgen dalam rangka mendukung tercapainya kompetensi yang menjadi target pendidikan (Bonawati, 2007: 147). Buku teks dapat membantu menyediakan data dan pengajaran otonom kepada siswa untuk memperkaya pengetahuan dalam operasi pengajaran (Sholehhudin, Suyitno, \& Wardhani, 2020). Salah satu bagian penting dari buku teks adalah tugas, seperti memberikan pertanyaan, arahan, kegiatan, dan investigasi yang dapat ditemukan di buku, terutama di akhir bab (Andersson-Bakken, Jegstad, \& Bakken, 2020).

Pembelajaran sains sendiri selayaknya menggunakan metode discovery learning. Metode tersebut merupakan metode pembelajaran yang menekankan pada pola dasar seperti melakukan pengamatan, mengiferensi (menarik kesimpulan), dan mengkomunikasikan. Pola yang terdapat pada metode discovery learning tersebut merupakan pola yang terdapat pada pendekatan keterampilan scientic process. Standar proses dan kurikulum 2013 dapat diperjelas dalam bentuk silabus, buku guru, dan buku siswa. Dengan demikian, penelitian ini melakukan kajian dan analisis terhadap satu buku siswa kurikulum 2013 yang digunakan dalam proses pembelajaran dan dalam rangka mengetahui pembelajaran yang dilakukan berdasarkan pendekatan keterampilan proses sains dasar sebagai kaidah pembelajaran pada materi IPA bagi siswa MI/SD.

Keterampilan proses sains merupakan keterampilan yang diperlukan dan dapat digunakan dalam memahami fenomena apa saja yang terjadi. Menurut Rustaman dalam Lepiyanto (2014: 156), keterampilan proses sains merupakan keterampilan yang diperlukan untuk memperoleh, mengembangkan, dan menerapkan konsep-konsep dan 
hukum-hukum yang ada pada sains, baik berupa keterampilan mental, keterampilan fisik, maupun keterampilan sosial. Samatowa dalam Lepiyanto (2014: 156) mengungkapkan bahwa keterampilan proses sains ialah keterampilan intelektual yang dimiliki dan digunakan oleh para ilmuwan dalam penelitian fenomena alam. Keterampilan proses sains ialah salah satu keterampilan yang dibutuhkan demi mencapai, mengembangkan, dan mengaplikasikan konsep, prinsip, hukum, fakta, dan teori sains. Keterampilan ini melibatkan keterampilan kognitif dan intelektual yang diharapkan mampu memperluas penguasaan konsep yang telah dimiliki siswa dalam pembelajaran, sehingga keterampilan proses sains dapat berpengaruh pada penguasaan konsep pada ranah kognitif (Desstya, 2015: 97). Menurut Padila dalam Rahayu \& Anggreani (2017: 24), keterampilan proses terdiri atas keterampilan dasar dan keterampilan terintegrasi. Keterampilan dasar mencakup enam keterampilan, yaitu mengobservasi, mengklasifikasi, memprediksi, mengukur, inferensi, dan mengkomunikasikan. Keterampilan integrasi terdiri atas sembilan keterampilan, yaitu mengidentifikasi variabel, membuat tabulasi data, menyajikan data dalam bentuk grafik, menggambarkan hubungan antar variabel, mengumpulkan data dan mengolah data, menganalisis penelitian, menyusun hipotesis, mendefinisikan variabel secara operasional, dan merancang penelitian atau eksperimen.

Rendahnya kemampuan sains siswa Indonesia tampak pada studi dari Program for International Student Assessment (PISA) yang dilakukan oleh Organization for Economic Cooperation and Development (OECD) yang menyatakan bahwa berdasarkan hasil survei yang dilakukan, Indonesia berada pada urutan 74 dari 79 negara atau posisi keenam dari bawah. Dalam kategori sains, Indonesia memperoleh skor 396 dan jauh dari rata-rata skor OCED sebesar 489 (Faradila, 2019). Berdasarkan pernyataan tersebut, dapat diketahui bahwa keterampilan sains anak Indonesia masih sangat kurang. Hal ini diakibatkan oleh berbagai faktor, baik dari materi sains yang tidak tersampaikan dengan baik karena siswa tidak terlibat langsung dalam proses belajar maupun keterampilan proses sains yang tidak dilatih secara optimal. Keterampilan proses sains dapat tercermin dalam buku ajar sains.

Chipeta, Filman, dan Sethna dalam Adisendjaja \& Romlah (2017) merekomendasikan empat tema yang harus dipertimbangkan dalam memilih buku ajar sains, yaitu: (1) sains sebagai pengetahuan, artinya sains menampilkan, mendiskusikan, atau menanyakan hal-hal untuk mengingat tentang fakta-fakta, konsep, prinsip, hukum, teori-teori, dan sebagainya, (2) sains sebagai cara investigasi, artinya sains menstimulasi berpikir dan melakukan sesuatu dengan menugaskan siswa untuk menyelidiki. Hal tersebut dapat dilihat dari aspek inkuiri dan belajar aktif. Selain itu, melibatkan siswa dalam proses sains seperti melakukan observasi, mengukur, melakukan klasifikasi, menarik kesimpulan, mencatat data, melakukan perhitungan, dan melakukan percobaan, (3) sains sebagai cara berpikir, artinya memberi gambaran sains secara umum dan ilmuwan secara khususnya dalam melakukan penyelidikan, dan (4) interaksi sains, teknologi, dan masyarakat, artinya memberi gambaran tentang pengaruh atau dampak sains terhadap masyarakat, sehingga perlu diketahui buku tematik siswa kelas $\mathrm{V}$ tema panas dan perpindahannya sudah termuat keterampilan proses sains atau tidak, khususnya KPS dasar.

Buku siswa dan buku guru adalah bentuk dokumen sebagai rincian dari standar proses dan kurikulum 2013, termasuk di dalamnya berisi konsep dan fakta sebagai produk sains dan telah dimanfaatkan oleh pegiat pendidikan. Buku tematik memuat beberapa mata pelajaran yang terintegrasi pada satu tema pembelajaran. Penelitian dan 
analisis ini mengkaji buku siswa kelas $\mathrm{V}$ tema panas dan perpindahannya untuk MI/SD, pada muatan materi IPA. Manfaat dari analisis ini yaitu memberikan informasi akan isi buku dari pembelajaran yang mengamalkan keterampilan proses sains.

\section{Metode Penelitian}

Penelitian ini menggunakan metode library research yaitu mengumpulkan dan menginformasikan data dengan bantuan macam-macam material yang terdapat di ruangan perpustakaan, seperti buku-buku, jurnal, majalah, koran, dan berbagai jenis laporan, seperti dokumen baik yang belum atau sudah diterbitkan (Wati \& Novianti, 2016: 3). Referensi tentang keterampilan proses sains dikumpulkan, ditafsirkan, dan dianalisis, kemudian dikaitkan dengan penyajian dalam materi IPA pada buku tematik siswa kelas V tema panas dan perpindahnnya yang ditulis oleh Diana Karitas dan Fransiska terbitan Kementrian Pendidikan dan Kebudayaan. Tema tersebut terletak pada tema 6 dan terdiri dari 226 halaman. Penelitian ini menggunakan pendekatan analisis deskriptif kualitatif. Data yang dikumpulkan berupa kata-kata dan gambar, bukan angka. Penelitian kualitatif merupakan penelitian yang menjabarkan secara deskriptif dengan menggunakan kata-kata selaras terhadap hasil yang diamati, berdasarkan aspek keterampilan proses sains (Elvanisi, Hidayat, \& Fadillah, 2018: 146).

\section{Hasil dan Pembahasan}

\subsection{Hasil}

Buku yang dianalisis yaitu buku tematik siswa kelas $\mathrm{V}$ tema panas dan perpindahannya, yang ditulis oleh Diana Karitas dan Fransiska terbitan Kementrian Pendidikan dan Kebudayaan. Tema tersebut terletak pada tema 6, terdiri dari 226 halaman, dan 4 subtema yaitu suhu dan kalor, perpindahan kalor sekitar kita, pengaruh kalor terhadap kehidupan, dan literasi. Pada buku tersebut, terdapat pembelajaran yang memuat materi IPA, yaitu pembelajaran 1, pembelajaran 2, dan pembelajaran 5 . Hasil analisis dari buku tematik siswa dapat disajikan pada tabel berikut:

Tabel 1. Hasil Analisis Keterampilan Proses Sains pada Materi IPA

\begin{tabular}{|c|c|c|c|}
\hline No & Subtema & Deskripsi Pembelajaran KPS Dasar & $\begin{array}{c}\text { Halaman } \\
\text { Buku }\end{array}$ \\
\hline \multirow{5}{*}{1} & \multirow{5}{*}{ Subtema 1} & $\begin{array}{l}\text { Aktivitas I: Observasi, mengelompokkan, } \\
\text { dan komunikasi. }\end{array}$ & $6-7$ \\
\hline & & $\begin{array}{l}\text { Aktivitas II: Observasi, mengukur, } \\
\text { inferensi/menarik kesimpulan, } \\
\text { komunikasi, dan memprediksi. }\end{array}$ & $7-8$ \\
\hline & & Aktivitas III: Observasi dan komunikasi & 14 \\
\hline & & $\begin{array}{l}\text { Aktivitas IV: Peramalan, observasi, } \\
\text { inferensi/menarik kesimpulan, dan } \\
\text { komunikasi. }\end{array}$ & $15-16$ \\
\hline & & $\begin{array}{l}\text { Aktivitas V: Observasi, inferensi/menarik } \\
\text { kesimpulan, komunikasi, dan peramalan. }\end{array}$ & 49 \\
\hline \multirow[t]{2}{*}{2} & \multirow[t]{2}{*}{ Subtema 2} & $\begin{array}{l}\text { Aktivitas I: Observasi, pengukuran, } \\
\text { inferensi/menarik kesimpulan, } \\
\text { komunikasi, dan peramalan. }\end{array}$ & $76-77$ \\
\hline & & Aktivitas II: Observasi, inferensi/menarik & $83-84$ \\
\hline
\end{tabular}




\begin{tabular}{|c|c|c|c|}
\hline No & Subtema & Deskripsi Pembelajaran KPS Dasar & $\begin{array}{c}\text { Halaman } \\
\text { Buku }\end{array}$ \\
\hline & & $\begin{array}{l}\text { kesimpulan, komunikasi, dan } \\
\text { memprediksi. }\end{array}$ & \\
\hline & & $\begin{array}{l}\text { Aktivitas III: Observasi, inferensi/menarik } \\
\text { kesimpulan, komunikasi, dan } \\
\text { mempredeksi. }\end{array}$ & $121-122$ \\
\hline \multirow{3}{*}{3} & \multirow{3}{*}{ Subtema 3} & $\begin{array}{l}\text { Aktivitas I: Observasi, mengelompokkan, } \\
\text { inferensi/menarik kesimpulan, dan } \\
\text { memprediksi. }\end{array}$ & 140 \\
\hline & & $\begin{array}{l}\text { Aktivitas II: Observasi, inferensi/menarik } \\
\text { kesimpulan, dan komunikasi. }\end{array}$ & 151 \\
\hline & & $\begin{array}{l}\text { Aktivitas III: Observasi, inferensi/menarik } \\
\text { kesimpulan, dan komunikasi. }\end{array}$ & $181-182$ \\
\hline 4 & Subtema 4 & Subtema 4 hanya terdapat materi literasi. & $200-217$ \\
\hline
\end{tabular}

\subsection{Pembahas an}

Dari tabel 1, dapat dijelaskan bahwa keseluruhan materi IPA yang terdapat pada buku tematik kelas $\mathrm{V}$ tema 6 tersebut mempunyai 6 keterampilan proses sains dasar, yaitu keterampilan observasi, mengklasifikasi, mengukur, memprediksi, inferensi, dan komunikasi. Pada subtema 1 (suhu dan kalor), terdapat 6 keterampilan proses sains dasar yang termuat pada subtema tersebut dan terdapat pada lima aktivitas. Aktivitas I yaitu observasi, komunikasi, dan mengelompokkan. Aktifitas II yaitu observasi, mengukur, komunikasi, menarik kesimpulan, dan memprediksi. Aktivitas III yaitu observasi dan komunikasi. Aktivitas IV yaitu peramalan, observasi, inferensi, dan komunikasi. Aktivitas V yaitu observasi, inferensi, komunikasi, dan memprediksi.

Data yang diobservasi siswa yaitu sumber energi yang digunakan pada kehidupan sehari-hari. Dari data yang ditemukan di lapangan, siswa melakukan pengelompokkan kegiatan yang menggunakan energi panas listrik dan kegiatan yang tidak menggunakan energi panas listrik. Observasi yang dilakukan pada aktivitas I yaitu mengamati proses percobaan yang dilakukan berkaitan dengan matahari sebagai sumber energi panas bagi kehidupan manusia. Dalam melakukan observasi, siswa mengamati secara detail proses yang terjadi terhadap es batu yang sudah mereka letakkan pada tiga tempat yang berbeda. Dalam melakukan observasi, siswa diharapkan dapat memantau perubahan dari kejadian awal sampai es batu mencair. Observasi merupakan salah satu bagian dari pembelajaran IPA yang memerlukan kegiatan penyelidikan sebagai bagian dari kerja ilmiah. Pembelajaran IPA mengembangkan rasa ingin tahu siswa melalui penemuan dengan pengalaman langsung yang dilakukan melalui kerja ilmiah. Melalui kerja ilmiah, siswa dilatih untuk memanfaatkan fakta, membangun konsep, prinsip, dan teori, sebagai dasar untuk berpikir kreatif, kritis, analitis, dan berbeda (Wati \& Novianti, 2016: 134).

Keterampilan observasi pada aktivitas II yaitu mengamati gambar-gambar yang berhubungan dengan energi panas pada koran. Siswa mengamati gambar-gambar yang terdapat pada koran yang merupakan peralatan yang sering digunakan dalam lingkungan keluarga dan menggunakan energi panas, baik dari energi panas listrik maupun energi panas lainnya/baterai. Pada aktivitas V, siswa mengamati cara kerja alat pengukur tempratur panas/termometer. Siswa mengamati perubahan yang terjadi terhadap hasil percobaan yang sedang dilakukan. Seperti, untuk mengetahui air dalam botol yang 
sudah diberi pewarna makanan akan naik pada rongga sedotan yang dimasukan pada botol yang sedikit menyentuh permukaan air dalam botol tersebut ketika diberikan perlakukan menyentuhkan botol pada kain hangat atau tidak, botol tersebut sudah ditutup rapat dengan tanah liat. Pada aktivitas IV dan V, observasi yang dilakukan yaitu pengamatan yang melibatkan indera penglihatan.

Pada keterampilan komunikasi, siswa diharapkan mampu menyampaikan dan menyajikan hasil dari temuannya kepada siswa lain dan guru dengan cara membuat laporan penelitian, mulai dari menyusun karangan, menyampaikan informasi dalam bentuk tabel, grafik, gambar, dan lainnya, hingga menceritakan pengalaman dalam melakukan pengamatan. Pada aktivitas I, siswa mengembangkan keterampilan komunikasinya dengan menyajikan hasil temuannya melalui tabel pengamatan. Pada aktivitas II, III, IV, dan V, keterampilan komunikasi yang dapat dilakukan siswa yaitu dengan menjelaskan hasil pengamatannya kepada siswa lain dan guru. Aktivitas ini dilakukan di depan kelas maupun di dalam kelompoknya. Sebelum dikomunikasikan, siswa harus dapat menarik kesimpulan dari hasil pengamatannya.

Keterampilan mengukur yang dilakukan pada aktivitas II diterapkan dengan cara siswa mengukur waktu yang dibutuhkan masing-masing wadah es batu mencair sempurna yang disimpan pada tiga tempat berbeda. Keterampilan memprediksi merupakan dugaan terhadap suatu yang akan terjadi masa mendatang atas data dan dasar kejadian yang setelah diketahui. Prediksi sendiri berdasarkan hasil observasi, pengukuran, maupun informasi tentang hubungan antara variabel dan observasi. Keterampilan prediksi dalam sub tema 1 terdapat pada aktivitas II. Kerampilan prediksi berkaitan dengan hubungan es batu dapat lebih cepat cair ketika terkena energi panas matahari dan es batu yang terlindungi matahari akan lebih lambat dan membutuhkan banyak waktu untuk dapat cair.

Subtema 2 yaitu perpindahan kalor di sekitar kita. Kegiatan yang sesuai aspek keterampilan proses sains dasar pada subtema ini tediri dari tiga aktivitas. Aktivitas I yaitu observasi, pengukuran, inferensi, komunikasi, dan memprediksi. Aktivitas II yaitu observasi, inferensi, komunikasi, dan memprediksi. Aktivitas III yaitu observasi, inferensi, komunikasi, dan memprediksi. Observasi yang dilakukan harus dapat melibatkan seluruh alat indera, bukan hanya mengamati dengan melihat tetapi dapat menggunakan kulit untuk meraba dan merasakan hal yang mungkin tidak dapat dijangkau oleh indera penglihatan, agar data yang didapatkan valid dan menyeluruh. Pada aktivitas I dan III, observasi yang dilakukan menggunakan indera perasa. Siswa melakukan observasi dengan merasakan untuk dapat mengetahui kalor dapat berpindah secara reduksi maupun radiasi atau tidak. Pada aktivitas ini, siswa melakukan observasi dengan memegang ujung sendok beberapa menit dan dimasukkan ke dalam air panas, sedangkan siswa melakukan pengamatan menggunakan indera peraba dengan cara mendekatkan ujung jarinya pada lilin yang menyala dan sebelumnya sudah diukur jarak antar jari dengan lilin yang sesuai dengan langkah kerja percobaan. Pada aktivitas II, dilakukan dengan menggunakan dan memanfaatkan indera penglihatan. Siswa mengamati kejadian yang terjadi pada es batu yang dimasukan ke dalam air panas dalam gelas.

Keterampilan komunikasi yang dilakukan pada subtema perpindahan kalor di sekitar kita yaitu siswa dituntut untuk dapat menyampaikan hasil pengamatannya dengan cara menjelaskan hasilnya tersebut kepada teman-teman kelasnya. Kegiatan untuk mengaplikasikan konsep tersebut yaitu siswa terlebih dahulu menarik kesimpulan dari hasil observasinya tersebut, kemudian memprediksikan hal yang dapat terjadi pada 
peristiwa atau observasi selanjutnya jika berhadapan dengan kondisi yang sama sesuai hasil pengamatannya sekarang. Keterampilan yang sesuai dengan aspek keterampilan proses sains dasar pada subtema 2 terdapat kegiatan mengobservasi, pengukuran, menarik kesimpulan/inferensi, mengkomunikasikan, dan memprediksi. Pada subtema 2, tidak terlihatnya keterampilan untuk mengelompokkan.

Subtema 3 yaitu pengaruh kalor terhadap kehidupan. Terdapat tiga aktivitas yang sesuai dengan aspek keterampilan proses sains dasar. Aktivitas I yaitu observasi, mengelompokkan, menarik kesimpulan, dan memprediksi. Aktivitas II yaitu observasi, menarik kesimpulan, dan komunikasi. Aktivitas III yaitu observasi, menarik kesimpulan, dan komunikasi. Observasi yang dilakukan pada kegiatan I yaitu siswa melakukan pengamatan menggunakan indera perasanya. Siswa melakukan percobaan untuk mengetahui kemampuan menghantar panas sebuah benda. Jadi, yang dilakukan siswa yaitu mengobservasi kemampuan benda-benda yang dipegangnya mampu menghantar panas dengan baik atau tidak. Observasi yang dilakukan pada aktivitas II ini menggunakan indera penglihatan, yaitu siswa melihat benda-benda yang ada di sekitarnya (sekolah/rumah) untuk mengidentifikasi sifat hantaran benda tersebut dan kegunaanya dalam keseharian. Pada aktivitas III, observasi yang dilakukan siswa dengan memanfaatkan dan menggunakan indera penglihatan, yaitu siswa mengamati peralatan yang menggunakan bahan konduktor dan isolator di sekitarnya. Objek yang diamati merupakan peralatan yang terdapat di rumah, dilihat dari aspek bahan yang digunakan, kegunaan, dan sifat hantarannya.

Keterampilan observasi sebagian besar dilakukan dengan indera penglihatan. Berdasarkan teori Piaget, bahwa anak yang masih MI/SD berada pada tahap perkembangan kongnitif operasional kongkret (7-12 tahun), termasuk anak yang duduk pada bangku kelas 5. Anak masih sangat membutuhkan benda-benda kongkret, benda yang dapat dilihat secara langsung, untuk membantu pengembangan kemampuan intelektualnya. Pada aktivitas I, siswa dituntut untuk dapat mengelompokkan bendabenda yang ditemukannya tersebut, mengelompokkan benda yang termasuk benda konduktor atau isolator. Pada aktivitas I dan II, hasil pengamatannya dituangkan pada tabel pengamatan dan siswa harus mampu menyampaikan dan menjelaskan hasilnya kepada teman-teman di dalam kelompok maupun keseluruhan kelas. Menurut Yusefni \& Sriyati (2016: 9-17), berkomunikasi tidak hanya dapat dilakukan secara lisan, berkomunikasi juga dapat dilakukan dalam bentuk tulisan. Keterampilan siswa berkomunikasi secara tulisan dapat membantu siswa dalam mentransfer dan menyajikan ilmu secara konsisten dan benar agar siswa tidak salah dalam menggeneralisasi informasi yang diperoleh. Sebelum dilakukan komunikasi, terlebih dahulu siswa sudah menarik kesimpulan dari hasil pengamatann tesebut. Kemudian memprediksikan hal yang dapat terjadi jika dihadapkan dengan kejadian atau pengalaman yang sama. Pada subtema 4, tidak terdapat pembelajaran IPA sehingga tidak didapatkan keterampilan proses sains dasar pada subtema ini. Subtema 4 hanya mambahas tentang kegiatan literasi. Materi literasi yang terdapat pada subtema 4 yang terdapat pada buku tematik siswa kelas $\mathrm{V}$ tema panas dan perpindahannya hanya berisi cerita-cerita, lalu siswa diarahkan untuk membaca dan menganalisis cerita yang dibaca dan tidak ada materi IPA di dalamnya. Terdapat 6 cerita pada subtema 4 dengan berbagai judul dan kisah yang dapat diambil dan meningkatkan pengetahuan/berpikir tingkat tinggi dan literasi siswa. Hal ini sesuai dengan pengertian literasi, yaitu berpikir kritis, dapat menghitung, memecahkan masalah, cara mencapai tujuan, mengembangkan ilmu pengetahuan, dan potensi seseorang (Subandiyah, 2017: 112). 
Pada pembelajaran IPA kelas $\mathrm{V}$ tema panas dan perpindahannya sudah terdapat 6 keterampilan proses sains, dengan menggunakan berbagai model pembelajaran, namun belum ditemukan pembelajaran yang menerapkan model problem based learning. Tidak seperti yang terdapat pada penelitian Nugroho \& Imron (2019) yang memaparkan bahwa keterampilan proses sains mengalami peningkatan dan berdampak pada karakteristik Islami yang ditunjukan pada sikap keseharian siswa saat diterapkannya pembelajaran dengan model problem based learning. Dilihat dari hasil penelitiannya, bahwa pada siklus pertama tergolong cukup baik dan siklus kedua tergolong cukup baik juga, hanya saja mengalami peningkatan sebesar 3,26\%. Sedangkan, karakteristik siswa pada siklus I berada pada kategori baik dan siklus II berada pada kategori baik pula, tetapi mengalami peningkatan sebesar 5,96\%. Penelitian Hasrawati (2016) mengkaji tentang perangkat pembelajaran tematik, implementasi dari pembelajaran tematik, dan hambatan dalam menerapkannya. Sedangkan, penelitian yang kami teliti yaitu analisis buku tematik siswa berdasarkan aspek keterampilan proses sains dasar. Penelitian ini mengkaji tentang pembelajaran tematik, hanya saja berbeda pada cakupan dari penelitiannya.

\section{Simpulan}

Adapun kesimpulan dari penelitian ini yaitu: (1) tiap subtema buku siswa kelas $\mathrm{V}$ tema panas dan perpindahannya telah sesuai dengan acuan pada pembelajaran dengan pendekatan keterampilan proses sains dasar, (2) setiap subtema termuat keterampilan proses sains dasar meliputi observasi dan komunikasi, inferensi, pengelompokkan, dan penalaran, namun tidak ditemukan keterampilan proses sains dasar pada subtema 4, karena hanya memuat materi literasi.

\section{Daftar Pustaka}

Adisendjaja, H. Y., \& Romlah, O. (2017). Analisis Buku Ajar Sains Bedarkan Literasi Ilmu sebagai Dasar untuk Memilih Buku Ajar Sains (Biologi). In Seminal Nasional Pendidikan Biologi di Jurusan Pendidikan Biologi FPMIPA UPI (pp. 1-8). Retrieved from http://file.upi.edu/Direktori/FPMIPA/JUR._PEND._ BIOLOGI/195512191980021-YUSUF_HILMI_ADISENDJAJA/ANALISIS_B UKU_AJAR_SAINS_BERDASARKAN_LITERASI_ILMIAH_SEBAGAI_DA SAR_UNTUK_MEMILIH_BUKU_AJAR_SAINS.pdf

Andersson-Bakken, E., Jegstad, K. M., \& Bakken, J. (2020). Textbook Tasks in the Norwegian School Subject Natural Sciences: What Views of Science Do They Mediate? International Journal of Science Education, 1-19. https://doi.org/ 10.1080/09500693.2020.1756516

Bonawati, E. (2007). Buku Teks Pembelajaran Geografi di Kota Semarang. Jurnal Geogafi FIS UNNES, 4(2), 147-158. https://doi.org/10.15294/jg.v4i2.106

Desstya, A. (2015). Keterampilan Proses Sains dan Pembelajaran IPA di Sekolah Dasar (Telaah Buku Siswa Kelas IV SD Tema 2 Karya Sumini). Profesi Pendidikan Dasar, 2(2), 95-102. Retrieved from http://journals.ums.ac.id/index.php/ppd/ article/view/1644/1170

Elvanisi, A., Hidayat, S., \& Fadillah, E. N. (2018). Analisis Keterampilan Proses Sains pada Sekolah Menengah Atas. Jurnal Inovasi Pendidikan IPA, 4(2), 145-152. https://doi.org/10.21831/jipi.v4i2.21426

Faradila, S. N. (2019). Menilik Kualitas Pendidikan Indonesia Menurut PISA 3 Periode 
Terakhir. Retrieved from https://kumparan.com/kumparansains/menilik-kualitaspendidikan-indonesia-menurut-pisa-3-periode-terakhir-1sO0SIXNroC/full

Hasrawati. (2016). Perangkat Pembelajaran Tematik di Sd. AULADUNA: Jurnal Pendidikan Dasar Islam, 3(1), 37-49. https://doi.org/10.24252/auladuna.v3ila5. 2016

Lepiyanto, A. (2014). Analisis Keterampilan Proses Sains pada Pembelajaran Berbasis Praktikum. BIOEDUKASI (Jurnal Pendidikan Biologi), 5(2), 156-161. https://doi.org/10.24127/bioedukasi.v5i2.795

Martatik. (2018). Analisis Buku Bahasa Arab Pendekatan Saintifik Kurikulum 2013 Madrasah Ibtidaiyah Kelas I. Andragogi: Jurnal Diklat Teknis Pendidikan Dan Keagamaan, 6(1), 104-121. https://doi. org/10.36052/andragogi.v6i1.50

Nugroho, I., \& Imron. (2019). Implementasi Model Based Learning (PBL) pada Keterampilan Proses dan Karakter Islami Peserta didik dalam Pembelajaran Sains di MI. AULADUNA: Jurnal Pendidikan Dasar Islam, 6(2), 130-137. https://doi.org/10.24252/auladuna.v6i2a3.2019

Pemerintah Indonesia. (2003). Undang-Undang Republik Indonesia Nomor 20 Tahun 2003 tentang Sistem Pendidikan Nasional. Jakarta: Sekretariat Negara.

Rahayu, A. H., \& Anggreani, P. (2017). Analisis Profil Keterampilan Proses Sains Siswa Sekolah Dasar di Kabupaten Sumedang. Jurnal Pesona Dasar, 5(2), 2233. Retrieved from http://www.jurnal.uns yiah.ac.id/PEAR/article/view/8847

Sholehhudin, M., Suyitno, \& Wardhani, N. E. (2020). Evaluating the Use of Multicultural-Based Short Story Appreciation Textbook to Teach Prose-Fiction Appreciation Course. International Journal of Instruction, 13(1), 831-844. Retrieved from https://files.eric.ed.gov/fulltext/EJ1239285.pdf

Subandiyah, H. (2017). Pembelajaran Literasi dalam Mata Pelajaran Bahasa Indonesia. Paramasastra, 2(1), 111-123. https://doi.org/10.26740/parama.v2i1.1502

Wati, W., \& Novianti. (2016). Pengembangan Rubrik Asesmen Keterampilan Proses Sains pada Pembelajaran IPA SMP. Jurnal Ilmiah Pendidikan Fisika Al-Biruni, 5(1), 131-140. https://doi. org/10.24042/jpifalbiruni.v5i1.113

Yusefni, W., \& Sriyati, S. (2016). Pembelajaran IPA Terpadu Menggunakan Pendekatan Science Writing Heuristic untuk Meningkatkan Kemampuan Komunikasi Tulisan Siswa SMP. EDUSAINS, 8(1), 9-17. https://doi.org/ 10.15408/es.v8i1. 1562 